\title{
Impact of Lime and Secondary Nutrient Management on Economics of Paddy Cultivation in Coastal Karnataka, India
}

\author{
S. M. Jayaprakash ${ }^{1 *}$, S. U. Patil' ${ }^{2}$, T. H. Ranjith ${ }^{1}$, R. Jayaprakash ${ }^{3}$ \\ and K. V. Sudhir Kamath ${ }^{4}$ \\ ${ }^{1}$ Department of Soil Science \& Agricultural Chemistry, ZAHRS, Brahmavar, India \\ ${ }^{2}$ ZAHRS, Brahmavar, India \\ ${ }^{3}$ Krishi Vigyan Kendra, Brahmavar, Udupi, India \\ ${ }^{4}$ Department of Agronomy ZAHRS, Brahmavar, India \\ *Corresponding author
}

Keywords

Paddy, economics, acidity, lime, levels, B: C ratio, kharif

Article Info

Accepted:

15 January 2020

Available Online:

10 February 2020

\section{A B S T R A C T}

A field experiment was conducted during kharif of 2014, 2015 and 2016 at Zonal Agricultural and Horticultural Research Station, Brahmavar, Udupi district, Karnataka, to study the economics of paddy cultivation in soil acidity and secondary nutrient management practices. The experiment was laid out in RCBD design with three replications and nine treatments involving different levels of lime applications and magnesium sulphate in comparison to package of practice as control. Economics of paddy cultivation in soil acidity and secondary nutrient management practices was studied for three years 2014, 2015 and 2016. Results over three years of experimentation clearly shows that significantly higher net returns and B:C ratio was obtained in treatment $\mathrm{T}_{4}: 100 \% \mathrm{NPK}+$ Lime application equivalent to $50 \%$ exch. Acidity $+30 \mathrm{~kg}$ magnesium sulphate and followed by treatment $\mathrm{T}_{5}: 100 \% \mathrm{NPK}+$ Lime application equivalent to $50 \%$ exch. Acidity $+40 \mathrm{~kg}$ magnesium sulphate.

\section{Introduction}

Globally, agriculture has to produce more food from less area of land through more efficient use of natural resources in order to meet the growing demands of increasing population (Hobbs, Sayre, \& Gupta, 2008). In India rice crop plays vital role in our national food security and is a means of livelihood for millions of rural households. India is the world's second largest producer (129.2 million tonnes) of rice on an area of 43 million ha and with the productivity of 3 tonnes per ha (ASG. 2015.) and ranks next to china. At the accelerating current growth rate of 1.8 per cent of population in India rice 
requirement by $2020 \mathrm{AD}$ is projected around 140 million tonnes. The rapid increasing in food production over the past three decades was at the cost of corresponding increase in the removal of nutrient from the soil.

Soil fertility is a dynamic natural property and it can change under the influence of natural and human induced factors. Soil organic matter is an important factor in deciding management system of the forest soil fertility. The forest soils vary in physico-chemical changes with time and space resulting in variation among topography, climate, weathering processes, vegetation cover and microbial activities and also biotic and abiotic factors (Sannappa and Manjunath., 2013).

In acidic soils less availability of nutrients $(\mathrm{N}$, $\mathrm{P}, \mathrm{K}, \mathrm{Ca}, \mathrm{Mg}$ and $\mathrm{S}$ ) besides inadequate nutrient management practices. Paddy is a exhaustive crops and removes large amount of macro and micro nutrients from soil (Singh and Singh, 2001). Though many nutrient management studies have been carried out in paddy, the location specific study on soil acidity and secondary nutrient management in rice for the farmers of coastal region of Karnataka is not up to the mark.

Despite slow growth in paddy productivity, the production reached to 106.54 million tonnes in 2013-14. Increase in input prices including human labour did not deter farmers from increasing investment on inputs which resulted in reducing profitability in paddy production, particularly in regions of low paddy productivity (Subramanian, 2000).

There is a common concern about declining profitability in Indian agriculture and paddy production is not an exception. Indian economy experienced overall growth but there is a need to understand the causes of distress in farming and production of principal crops. Keeping in view these observations, an attempt has been made in this paper to explore trends in cost of cultivation and profitability among paddy farmers in Bihar and Punjab which have almost contrasting scenario in productivity and use of inputs. Keeping the above points in view, a field experiment was carried out to study the economics of paddy cultivation in soil acidity and secondary nutrient management practices.

\section{Materials and Methods}

A field experiment was conducted during kharif season of 2014, 2015 and 2016 at Zonal Agricultural and Horticultural Research Station, Brahmavar, Udupi district, Karnataka, to study the economics of paddy cultivation in soil acidity and secondary nutrient management practices. The experimental site is situated between $74^{\circ} 45^{\text {, }}$ to $74^{\circ} 46^{\prime}$ East longitude and $13^{0} 24^{\prime} 45^{\prime \prime}$ to $13^{0} 25^{\prime}$ North latitude and an altitude of 25 meters above mean sea level.

Soil type is sandy loam in texture and $\mathrm{pH}$ was acidic (5.24). The soil was medium in available nitrogen (348.70 kg ha-1), high in available phosphorus (89.21 kg ha-1) and medium in available potassium $(62.08 \mathrm{~kg}$ ha-1 ). The organic carbon content was high $(0.968$ $\%$ ) in range. MO-4 (Red rice) a popular medium duration variety was transplanted in July with a spacing of $20 \mathrm{~cm}$ X $10 \mathrm{~cm}$.

Experiment included nine treatments treatments consisted of $\mathrm{T}_{1}: 100 \%$ NPK (POP; $\mathrm{N}: \mathrm{P}: \mathrm{K}=60: 30: 60 \mathrm{kgs} / \mathrm{ha}), \mathrm{T}_{2}: \mathrm{T}_{1}+100 \%$ NPK Lime application equivalent to $50 \%$ exch. Acidity, $\mathrm{T}_{3}: \mathrm{T}_{2}+20 \mathrm{~kg}$ magnesium sulphate, $\mathrm{T}_{4}: \mathrm{T}_{2}+30 \mathrm{~kg}$ magnesium sulphate, $\mathrm{T}_{5}: \mathrm{T}_{2}+40 \mathrm{~kg}$ magnesium sulphate, $\mathrm{T}_{6}: \mathrm{T}_{1}+$ Lime application equivalent to $100 \%$ exch. Acidity, $\mathrm{T}_{7}: \mathrm{T}_{6}+20 \mathrm{~kg}$ magnesium sulphate, $\mathrm{T}_{8}: \mathrm{T}_{6}+30 \mathrm{~kg}$ magnesium sulphate, $\mathrm{T}_{9}: \mathrm{T}_{6}+$ $40 \mathrm{~kg}$ magnesium sulphate. Yield (biological 
and economical) was recorded from individual plots at harvest and converted to $\mathrm{kg} / \mathrm{ha}$. Gross income from paddy cultivation is sum of values of main and by product which was estimated to know the net returns.

Standard statistical methods were used for comparing the treatment means. For comparing the increase in cost of cultivation and value of produce, the percentage change of both were calculated across the years. Relative change in increase in value of produce in comparison to cost of cultivation was calculated.

\section{Results and Discussion}

Effect of soil acidity and secondary nutrient management on grain and straw yield is presented in Table 1. After three years of experiment, the data obtained on grain and straw yield is pooled and analyzed statistically.

Result shows that the application of lime and secondary nutrients along with recommended dose of nutrients had very good impact to improve the soil available nutrients that resulted in higher grain yield in case of treatment $\mathrm{T}_{4}\left(7460 \mathrm{~kg} \mathrm{ha}^{-1}\right): \mathrm{T}_{2}+30 \mathrm{~kg}$ magnesium sulphate followed by the treatment $\mathrm{T}_{5}\left(7288 \mathrm{~kg} \mathrm{ha}^{-1}\right): \mathrm{T}_{2}+40 \mathrm{~kg}$ magnesium sulphate, $\mathrm{T}_{9}\left(7049 \mathrm{~kg} \mathrm{ha}^{-1}\right): \mathrm{T}_{6}+$ $40 \mathrm{~kg}$ magnesium sulphate but other treatments showed non-significant difference among the them.

Table.1 Effect of Lime application and secondary nutrient management on Grain and straw yield of paddy over the years $\left(\mathrm{Kg} \mathrm{ha}^{-1}\right)$

\begin{tabular}{|c|c|c|c|c|c|c|c|}
\hline \multicolumn{2}{|r|}{ Treatments } & \multicolumn{2}{|c|}{2014} & \multicolumn{2}{|c|}{2015} & \multicolumn{2}{|c|}{2016} \\
\hline & & $\begin{array}{c}\text { Grain } \\
\text { yield }\end{array}$ & $\begin{array}{c}\text { Straw } \\
\text { yield }\end{array}$ & $\begin{array}{c}\text { Grain } \\
\text { yield }\end{array}$ & $\begin{array}{c}\text { Straw } \\
\text { yield }\end{array}$ & $\begin{array}{c}\text { Grain } \\
\text { yield }\end{array}$ & $\begin{array}{c}\text { Straw } \\
\text { yield }\end{array}$ \\
\hline $\mathbf{T}_{1}$ & $\begin{array}{c}100 \% \text { NPK } \\
\text { (POP;N:P:K= 60:30:60 } \\
\text { kgs/ha) }\end{array}$ & 5743 & 6318 & 5685 & 6338 & 5648 & 6683 \\
\hline $\mathbf{T}_{2}$ & $\mathrm{~T}_{1}+$ Lime $50 \% \mathrm{EA}$ & 6343 & 7612 & 6362 & 7203 & 6285 & 7055 \\
\hline $\mathbf{T}_{3}$ & $\mathrm{~T}_{2}+20 \mathrm{~kg} \mathrm{MgSO}$ & 6580 & 7567 & 6432 & 7053 & 6598 & 7773 \\
\hline $\mathbf{T}_{4}$ & $\mathrm{~T}_{2}+30 \mathrm{~kg} \mathrm{MgSO}$ & 7677 & 8598 & 7365 & 7680 & 7460 & 7945 \\
\hline $\mathbf{T}_{5}$ & $\mathrm{~T}_{2}+40 \mathrm{~kg} \mathrm{MgSO}$ & 7366 & 8619 & 7010 & 7750 & 7288 & 8245 \\
\hline $\mathbf{T}_{6}$ & $\mathrm{~T}_{1}+$ Lime $100 \% \mathrm{EA}$ & 6647 & 7977 & 6495 & 8050 & 6593 & 7615 \\
\hline $\mathbf{T}_{7}$ & $\mathrm{~T}_{6}+20 \mathrm{~kg} \mathrm{MgSO}_{4}$ & 6776 & 7793 & 6530 & 7593 & 7003 & 7660 \\
\hline $\mathbf{T}_{8}$ & $\mathrm{~T}_{6}+30 \mathrm{~kg} \mathrm{MgSO}$ & 7217 & 8588 & 6780 & 7840 & 6925 & 7580 \\
\hline $\mathbf{T}_{9}$ & $\mathrm{~T}_{6}+40 \mathrm{~kg} \mathrm{MgSO}_{4}$ & 7184 & 8406 & 6620 & 7565 & 7049 & 7447 \\
\hline & SEM \pm & 95.173 & 110.16 & 136.44 & 284.17 & 88.21 & 202.96 \\
\hline & $\mathrm{CV}$ & 2.915 & 2.939 & 4.236 & 7.952 & 2.704 & 5.590 \\
\hline & $\mathrm{CD}(5 \%)$ & 291.23 & 340.4 & 407.551 & 865.53 & 266.74 & 617.21 \\
\hline
\end{tabular}


Table.2 Comparison of crop performance and B: C ratios among the treatments over the years

\begin{tabular}{|c|c|c|c|c|c|c|c|c|c|c|c|}
\hline \multirow{3}{*}{\multicolumn{2}{|c|}{ Treatments }} & \multicolumn{3}{|c|}{2014} & \multicolumn{3}{|c|}{2015} & \multicolumn{3}{|c|}{2016} & \multirow{2}{*}{$\begin{array}{l}\text { Pooled } \\
\text { B:C } \\
\text { ratio }\end{array}$} \\
\hline & & $\begin{array}{c}\text { Grain } \\
\text { yield }\end{array}$ & $\begin{array}{l}\text { Straw } \\
\text { yield }\end{array}$ & B:C & $\begin{array}{c}\text { Grain } \\
\text { yield }\end{array}$ & $\begin{array}{c}\text { Straw } \\
\text { yield }\end{array}$ & B:C & $\begin{array}{c}\text { Grain } \\
\text { yield }\end{array}$ & $\begin{array}{c}\text { Straw } \\
\text { yield }\end{array}$ & B:C & \\
\hline & & $\mathrm{Kg} / \mathrm{ha}$ & $\mathrm{Kg} / \mathrm{ha}$ & & $\mathrm{Kg} / \mathrm{ha}$ & $\mathrm{Kg} / \mathrm{ha}$ & & $\mathrm{Kg} / \mathrm{ha}$ & $\mathrm{Kg} / \mathrm{ha}$ & & \\
\hline $\mathbf{T}_{1}$ & $\begin{array}{l}\text { 100\% NPK } \\
\text { (POP;N:P:K= } \\
60: 30: 60 \mathrm{kgs} / \mathrm{ha})\end{array}$ & 5743 & 6318 & 1.772 & 5685 & 6338 & 1.732 & 5648 & 6683 & 1.687 & 1.730 \\
\hline $\mathbf{T}_{2}$ & $\mathrm{~T}_{1}+$ Lime $50 \% \mathrm{EA}$ & 6343 & 7612 & 2.042 & 6362 & 7203 & 1.981 & 6285 & 7055 & 1.879 & 1.967 \\
\hline $\mathbf{T}_{3}$ & $\mathrm{~T}_{2}+20 \mathrm{~kg} \mathrm{MgSO}$ & 6580 & 7567 & 2.066 & 6432 & 7053 & 1.959 & 6598 & 7773 & 1.976 & 2.000 \\
\hline $\mathbf{T}_{4}$ & $\mathrm{~T}_{2}+30 \mathrm{~kg} \mathrm{MgSO}_{4}$ & 7677 & 8598 & 2.377 & 7365 & 7680 & 2.199 & 7460 & 7945 & 2.158 & 2.246 \\
\hline $\mathbf{T}_{5}$ & $\mathrm{~T}_{2}+40 \mathrm{~kg} \mathrm{MgSO}_{4}$ & 7366 & 8619 & 2.295 & 7010 & 7750 & 2.114 & 7288 & 8245 & 2.131 & 2.180 \\
\hline $\mathbf{T}_{6}$ & $\mathrm{~T}_{1}+$ Lime $100 \% \mathrm{EA}$ & 6647 & 7977 & 2.076 & 6495 & 8050 & 2.016 & 6593 & 7615 & 1.930 & 2.007 \\
\hline $\mathbf{T}_{7}$ & $\mathrm{~T}_{6}+20 \mathrm{~kg} \mathrm{MgSO}_{4}$ & 6776 & 7793 & 2.064 & 6530 & 7593 & 1.964 & 7003 & 7660 & 1.995 & 2.008 \\
\hline $\mathbf{T}_{8}$ & $\mathrm{~T}_{6}+30 \mathrm{~kg} \mathrm{MgSO}_{4}$ & 7217 & 8588 & 2.207 & 6780 & 7840 & 2.024 & 6925 & 7580 & 1.962 & 2.064 \\
\hline $\mathbf{T}_{9}$ & $\mathrm{~T}_{6}+40 \mathrm{~kg} \mathrm{MgSO}$ & 7184 & 8406 & 2.173 & 6620 & 7565 & 1.957 & 7049 & 7447 & 1.966 & 2.032 \\
\hline & SEM \pm & 95.173 & 110.16 & & 136.44 & 284.17 & & 88.21 & 202.96 & & 0.025 \\
\hline & $\mathrm{CV}$ & 2.915 & 2.939 & & 4.236 & 7.952 & & 2.704 & 5.590 & & 2.079 \\
\hline & $\mathrm{CD}(5 \%)$ & 291.23 & 340.4 & & 407.551 & 865.53 & & 266.74 & 617.21 & & 0.078 \\
\hline
\end{tabular}

A significantly higher straw yield was obtained in case of treatment $\mathrm{T}_{5}(8245 \mathrm{~kg}$ ha $\left.{ }^{1}\right): \mathrm{T}_{2}+40 \mathrm{~kg}$ magnesium sulphate followed by treatment $\mathrm{T}_{4}\left(7945 \mathrm{~kg} \mathrm{ha}^{-1}\right): \mathrm{T}_{2}+30 \mathrm{~kg}$ magnesium sulphate and treatment $\mathrm{T}_{3}(7773$ $\left.\mathrm{kg} \mathrm{ha}{ }^{-1}\right): \mathrm{T}_{2}+20 \mathrm{~kg}$ magnesium sulphate. Similar observations were resulted by Taiwo Agbede and Lawrence Afolabi, 2014, and Rawat and Pareek (2003).

Results pertaining to the economics of paddy cultivation in soil acidity and secondary nutrient management practices are presented in table 2. After three years of experimentation, the data obtained on cost of cultivation, gross returns and net returns are analysed to know the $\mathrm{B}: \mathrm{C}$ ratio in order to know the economic benefit among the treatments. The data obtained on economics of paddy cultivation over the three years of experimentation is pooled and analyzed statistically.

Results over three years of experimentation clearly shows that significantly higher net returns and $\mathrm{B}: \mathrm{C}$ ratio was obtained in treatment $\mathrm{T}_{4}: 100 \% \mathrm{NPK}+$ Lime application equivalent to $50 \%$ exch. Acidity $+30 \mathrm{~kg}$ magnesium sulphate and treatment $\mathrm{T}_{5}: 100 \%$ $\mathrm{NPK}+$ Lime application equivalent to $50 \%$ each. Acidity $+40 \mathrm{~kg}$ magnesium sulphate followed by other treatments. same results are obtained by Newase et al., 1990, Subramanian et al., 2000 and Wani et al., 2009.

The present study has analysed the dynamics of cost of cultivation and profitability in paddy cultivation in Coastal Karnataka. However, performance in paddy cultivation in context of gross income to total cost improved during recent past which need further improvement for increasing profitability.

Efforts need to be taken to create an enabling environment to ensure a commensurate income to paddy farmers for improvement in their livelihood. Secondary nutrients like 
Calcium, Magnesium and sulfur plays its catalytic or stimulatory effect on physiological and metabolic activities in plants which ultimately influenced the significant increase in grain and straw yield.

Analysis of profitability revealed that the farmers received very little income or losses in paddy cultivation over total cost of cultivation during last decade mainly due to low productivity owing to less mechanization, low use of fertilizers and organic manure, low adoption level of modern technologies and changing weather scenarios.

\section{References}

Agricultural Statistics at a Glance, 2015, Directorate of Economics and Statistics, Department of Agriculture and Cooperation, Ministry of Agriculture, Government of India.

Newase, V. B., Waga, R. L., Thorat, S. T. and Patil, B. P., 1990, Production potential and economics of promising groundnut genotypes under varying levels of phosphorus in Konkan. J. Indian Society of coastal Agric. Rea., 8 (3).

Rawat, S.S. and Pareek, R.G., 2003. Effect of FYM and NPK on yield and nutrient uptake for soil fertility in wheat. Annals of Ari-BioResearch. 8(1): 17-19.

Rockstrom, J., Hatibu, N., Oweis, T. Y., Wani, S. P., Barron, J., Bruggeman, A., Qiang, Z. 2007. Managing water in rainfed agriculture. In D. Molden (Ed.), Water for food, water for life: A comprehensive assessment of water management in agriculture (pp. 315-348). London:
Earthscan and Colombo: International Water Management Institute, Sri Lanka.

Sannappa, B. and Manjunath, K.G. 2013. Fertility status of soils in the selected regions of the Western Ghats of Karnataka, India. Sch. Acad. J. Biosci., 1(5): 200-208.

Singh, A. C. and Singh, S. P., 2001. Growth and yield of spring sunflower and groundnut as influenced by different cropping systems and rates of nitrogen. Ann. Plant Soil Res., 3 (2): 222-225.

Subrahmanian, K. P., Kalaiselvan, and Arulmozhi, N. 2000. Studies on the effect of nutrient spray and graded level of NPK fertilizers on the growth and yield of groundnut. Internl. J. Trop. Agric., 18 (3): 287-290.

Taiwo M. Agbede and Lawrence a. Afolabi, 2014. Soil fertility improvement potentials of Mexican sunflower (Tithonia diversifolia) and Siam weed (Chromolaena odorata) using okra as test crop. Archives of Applied Science Research. 6 (2): 42-47.

Wani, S. P., Sarvesh, K. V., Krishnappa, K., Dharmarajan, B. K., \& Deepaja, S. M. (Eds.) 2012. Bhoochetana: Mission to boost productivity of rainfed agriculture through science-led interventions in Karnataka. Patancheru: International Crops Research Institute for the Semi-Arid Tropics.

Wani, S. P., Sreedevi, T. K., Rockstro“m, J., \& Ramakrishna, Y. S. 2009. Rainfed agriculture - Past trends and future prospects. In S. P. Wani, J. Rockstro“m, \& T. Oweis (Eds.), Rainfed agriculture: Unlocking the potential (pp. 1-35). Wallingford: $\quad \mathrm{CAB} \quad$ International, Comprehensive Assessment of Water Management in Agriculture Series.

\section{How to cite this article:}

Jayaprakash. S. M., S. U. Patil, T. H. Ranjith, R. Jayaprakash and Sudhir Kamath. K. V. 2020. Impact of Lime and Secondary Nutrient Management on Economics of Paddy Cultivation in Coastal Karnataka. Int.J.Curr.Microbiol.App.Sci. 9(02): 2234-2238. doi: https://doi.org/10.20546/ijcmas.2020.902.252 